\title{
PROLIFERATION OF CHAIN GROCERY STORES AND ITS EFFECTS ON FMCG DISTRIBUTORS' PERFORMANCE
}

\author{
ARGEE S. GALLARDO* AND ALAN T. CIPRIANO \\ Graduate School of Business, San Beda University, 638 Mendiola St, San Miguel, Manila, 1005, Philippines \\ *Corresponding author: gallardo_argee@yahoo.com
}

Submitted final draft: 2 December 2020

Accepted: 15 December 2020

http://doi.org/10.46754/jbsd.2021.03.003

\begin{abstract}
This study analyzed the effects of the proliferation of Chain Grocery Stores on the performance of the Fast-Moving Consumer Goods Exclusive Distributors in terms of Order Fill Rate, Delivery Timeliness, and Sales Level. The researchers used a 4-point Likert scale and encouraged the respondents to share their experiences to expound their answers. Survey results show that suppliers prioritize big Chain Grocery Stores than the FMCG Exclusive Distributors as the Chain Grocery Stores impose penalties for incomplete and delayed deliveries. On the proliferation of chain stores, Chain Grocery Stores comprise a total of $80 \%$ in Manila City and are in densely populated areas. The researchers recommend that FMCG Exclusive Distributors invest in a modern state-of-art system that links the stand-alone grocery stores> purchase order to the FMCG Exclusive Distributors' warehouse and purchasing team. As for Delivery Timeliness, the FMCG Exclusive Distributors should perform time and motion studies with their respective principals for a realistic delivery schedule. Manufacturers and country importers should consider an on-call third party logistics in cases of truck and personnel shortage. Lastly, assign a business development team to explore untapped areas of Manila City.
\end{abstract}

Keywords: Chain Grocery Stores Proliferation, distribution, Fast Moving Consumer Goods

\section{Introduction}

The supply chain management approach has often been implemented by companies to gain a competitive advantage, but it increases the susceptibility to certain risks of these supply chains (Rangel, de Oliveria \& Leite, 2014). Focusing on the grocery sector of the FMCG industry, the number of modern food retailers has considerably increased. There is some evidence of the displacement of small traditional vendors, and only a few independent supermarket suppliers flourished, despite the efforts of government and non-governmental organizations to help them enter modern food retailers (Digal, 2015). Moreover, the retail trade sector in the Philippines is growing faster than the overall economy. From 2000 to 2011, it grew by more than $7 \%$ compared to GDP's average increase of $5 \%$. Sales of leading retail chains grew by $17 \%$ during the period covered, which is a little higher compared to other second-wave countries like Thailand and Malaysia except Indonesia. From 2006 to 2010, grocery sales grew by $70 \%$ while food products increased by $87 \%$. Sales of fruits and vegetables increased faster than the average during this period. However, in earlier years from 2000 to 2005, the growth of fruits and food products category was only $20 \%$ compared to $34 \%$ growth of food products. The high growth rate of $70 \%$ in grocery sales and food products particularly from 2005 to 2010 was pulled up by the very high growth posted by Puregold where grocery and sales increased by more than $225 \%$ per year during this period. Taking out this outlier, the average growth of the top three retailers, SM, Robinsons and Rustans, during this period, was more than $30 \%$ with SM leading at $57 \%$ followed by Robinsons (Digal, 2015).

Looking at the supply chain of the FMCG industry, there are many channels from the manufacturers down to the end consumer. The 
grocery sector of the Philippines is growing. This is evident with the creeping presence of grocery stores mostly in densely populated areas. "Modern food retail markets have become essential, especially to those living in urban areas, as customers demand convenience and flexibility. Modern markets are expanding in both urban and rural areas, and close to residential and commercial communities" (Rubio, 2019, p. 3).

There are two types of grocery stores, namely, the Stand-Alone Grocery Stores and the Chain Grocery Stores. Normally, the StandAlone Grocery Stores are being served by the exclusive area distributors, while the Chain Grocery Stores purchase directly from the manufacturers through a central purchasing department of the mother company. This is the issue. Will distributors survive if there is a growing trend of chain grocery stores? Distributors only sell to stand alone grocery stores. Thus, this study seeks to know the effects of the proliferation of the Chain Grocery Stores on the FMCG Exclusive Distributors' performance in the City of Manila, namely: Order Fill Rate, Delivery Timeliness, and Sales Level.

Therefore, this research is significant to the policy makers as it can aid them in crafting legislation protecting the micro, small, and medium enterprises especially now that the economy has been hurt caused by the several or lingering lock downs brought by the Covid-19 Pandemic. Moreover, this study is helpful for those who wish to enter FMCG distribution and grocery businesses, and likewise useful for FMCG manufacturers and country importers who plan to improve their Supply Chain system.

According to Andrada, Prudenciano and Reyes (2020), a grocery store is a retail store that primarily sells food items and is between 300sq.m. and 1,400sq.m. in size. Due to the change in record-keeping system, this research is limited to the year 2020 data of registered grocery stores in the City of Manila. As for the FMCG distributors, only the exclusive distributors of known companies are included in this study.
Very little attention has been made regarding the FMCG Exclusive Distributors in the Philippines. There are limited studies on the relationship and effects of the proliferation of the chain stores vis-à-vis the FMCG Exclusive Distributors.

\section{Literature Review}

"Supply chains became increasingly susceptible to disruptions in material supplies. This is in part due to a highly volatile business environment and cost reduction efforts" (Johnson \& Nagarur, 2012, p. 3414). Distribution strategy is "one of the keys to determining product success in the market competition of Fast-Moving Consumer Goods (FMCG)" (Trihatmoko, Mulyani \& Lukviarman, 2018, p. 19). The distribution of FMCG products is made by distribution companies (distributors) which forward them to traditional and modern markets then to wholesalers, semi-wholesalers, and retailers (Trihatmoko \& Mulyani, 2018).

\section{Direct and Indirect Distribution Channel}

Distribution is the method of making a product or service available to a customer or company user for use or sale, by direct means, or by indirect means through intermediaries (Nyaga, 2014). A distribution system is said to be direct when the products go straight from the manufacturers to the end consumers with no middlemen involved. (Tetteh \& Xu, 2014). According to Chung, Chatterjee and Sengupta (2012), channel intermediaries are a key marketing asset that enables manufacturers to reach out to end-users or customers and serve them.

\section{FMCG and its Distribution}

According to Sarkar (2013), the FMCG market consists of non-lasting consumer products that generally include personal care, home care, food, and beverages. "Modern marketing practices across the globe talk about the efficiency of distribution management. The objective of timely placement of the right product to the right customer group brings challenges for 
the attainment of efficiency in the system of distribution" (Mandal, Bandyopadhyay \& Roy, 2011, p. 26). Further, according to the study of Sarkar (2013), "retailer is more satisfied with mechanized delivery mechanisms owing to the timeliness of deliveries. The in-depth interviews by the researcher also lead to the belief that retailers work on low investments in stocks and value the timeliness of deliveries" (Sarkar, 2013, p. 33). Sales value is also a factor that affects the degree of mechanization. This is highly anticipated as mechanized vehicles are generally higher in size- the only exception is the twowheeler mechanized which has less capacity than three-wheelers mechanized (Sarkar, 2013).

"The ultimate objective of every business is to increase the sales of goods that it deals in" (Patra, 2016, p. 74). Patra (2016) concluded that the "developments of distribution networks give strong support to the retailers and some basic ingredient of distribution give an instant stimulation of sales effectiveness and also highlight some important components of distribution and promotion have significant impacts on sales" (Patra, 2016, p. 74).

\section{Improving Supply Chain Performance}

Increasing competition and globalisation rates in the world economy have a major impact on seeking to improve the efficiency of supply chains. Companies are paying millions of dollars to improve their performance in the supply chain using process reengineering, new systems, training staff (Sayed, 2013). A good delivery network is one of the main factors for an FMCG company to do well. If a given FMCG company's distribution network is well oiled, then that particular FMCG company would undoubtedly find it much easier to go on the market (Nyaga, 2014).

\section{Grocery Sector}

As reported, in India the "fast-moving consumer goods (FMCG) distributors are feeling the pinch of the consumption slowdown...The association claims that
FMCG companies are offering better margins and incentives to modern trade... The margin differential is in the range of $15-20$ percent in many cases" (Sheth, 2019).

Independent grocery stores play an important role in the local communities, helping ensure food access for residents in areas that are not served by Chain Grocery Stores. These include low-income areas and rural cities. They also provide employment opportunities and generate tax revenue for these areas (Chung \& Myers, 1999; Block \& Kouba, 2006; Powell et al., 2007 as cited in Andrada, Prudenciano \& Reyes, 2020).

\section{Research Methods}

The researchers used mixed methods of data gathering. The quantitative approach used a 4-point Likert scale to measure the FMCG Exclusive Distributors' performance to ascertain the respondents' answer whether it is leaning towards agreement or disagreement to each statement, avoiding the possibility of a neutral survey result. This way, assessment and analysis will be more precise.

The respondents were also encouraged to share their insights, practices, and experiences to help expound their answers. Data gathering was conducted via phone in interview as that was the height of the Covid-19 pandemic wherein strict community quarantine was implemented by the national government.

To measure the proliferation of Chain Grocery Stores versus Stand-Alone Grocery Stores in the City of Manila, ratio type of quantitative analysis was used. The data was requested from the City of Manila Government - Permits Bureau.

There were only 51 FMCG Exclusive Distributors in the City of Manila. Exclusive Distributors are the intermediaries that exclusively distribute and sell manufactured or imported goods of a specific FMCG company. Examples of companies that grant exclusive distributorship are Unilever, Procter \& Gamble, Nestle, and Universal Robina Corporation. 
Using Slovin formula with 5\% margin of error, the computed sample size is 45 respondents.

Moreover, since the questionnaire is selfmade, it must be tested using the Cronbach Alpha to ensure reliability of the instrument. This was further validated by a statistician. Results show that Order Fill Rate and Delivery Timeliness have excellent remarks, while the
Sales Level indicated an acceptable result. This proved that the questionnaire is valid and ready for the actual data gathering.

Mean was used to describe each indicator and determine the average responses. On the other hand, Standard Deviation was used to determine if responses are close to one another or consistent.

\section{Results and Discussion}

\section{Order Fill Rate}

Table 1: Performance of FMCG exclusive distributors on order fill rate

\begin{tabular}{|c|c|c|c|}
\hline Indicators & Mean & SD & Interpretation \\
\hline $\begin{array}{l}\text { 1. Quantity of goods ordered per item is the same as the number of } \\
\text { goods delivered. }\end{array}$ & 3.04 & .67 & Agree \\
\hline 2. Goods delivered per SKU are always accurate as ordered. & 3.37 & .65 & Strongly Agree \\
\hline $\begin{array}{l}\text { 3. In cases when there is a supply shortage, the suppliers allocate more } \\
\text { stocks to the Chain Grocery Stores than the Exclusive Distributors. }\end{array}$ & 2.53 & .89 & Agree \\
\hline $\begin{array}{l}\text { 4. When there are concerns about the items ordered, the suppliers } \\
\text { always inform the distributors ahead of time. }\end{array}$ & 3.22 & .60 & Agree \\
\hline $\begin{array}{l}\text { 5. The supplier provides assistance to ensure goods are displayed in the } \\
\text { grocery stores. }\end{array}$ & 2.98 & .78 & Agree \\
\hline Weighted Mean & 3.03 & .39 & Agree \\
\hline
\end{tabular}

Legend: Strongly Agree 3.25-4; Agree 2.50-3.24; Disagree 1.75-2.49; Strongly Disagree 1.0-1.74

The table shows that respondents strongly agree when assessing the goods delivered versus the goods ordered. This is crucial as goods ordered signify what is usually purchased by the end consumers.

As for the other aspects of Order Fill Rate, results show that respondents agreed to the statements. Generally, the quantity of goods ordered, and the number of goods delivered are nearly accurate. A respondent shared that human error (e.g., error in encoding) affects the accuracy of volume or kind of goods delivered. When there is a supply shortage, there is a tendency that manufacturers and country importers prioritize the big Chain Grocery Stores as they impose penalties for incomplete goods delivered to make up for their opportunity losses. The company size and volume ordered by the big Chain Grocery Stores give them the leverage to demand what they want.
Study also shows that the manufacturers and country importers assign an area manager to work closely with the exclusive distributors. Thus, communications are always efficient and fast. Lastly, the manufacturers and country importers provide displayers to the Exclusive Distributors' clients (grocery stores) to ensure their items are always available on the shelves of the grocery stores.

The weighted mean of 3.03 for Order Fill Rate means that despite some setbacks experienced by the exclusive distributors, the manufacturers and country importers are still considered fairly efficient in serving the right kind and quantity of goods to the exclusive distributors. The standard deviation of .39 means the answers of the respondents are homogeneous as it is below 1.0. 


\section{Delivery Timeliness}

Table 2: Performance of FMCG exclusive distributors on delivery timeliness

\begin{tabular}{lcccc}
\hline \multicolumn{1}{c}{ Indicators } & Mean & SD & Interpretation \\
\hline 1. The suppliers (manufacturers and country importers) deliver on time & 3.02 & .75 & Agree \\
as scheduled. & & & & Agree \\
2. In cases of delivery disruption, it is caused by poor logistics planning. & 2.58 & .69 & Agree \\
$\begin{array}{l}\text { 3. Delivery delays are experienced when there are shortages of trucks } \\
\text { and/or personnel. }\end{array}$ & 3.02 & .66 & Agree \\
$\quad \begin{array}{l}\text { When delivery set-backs are experienced, the suppliers always } \\
\text { prioritize Chain Grocery Stores in the delivery schedule. }\end{array}$ & 2.67 & .90 & Agree \\
5. Unpredictable traffic situation affects delivery timeliness. & 3.16 & .77 & Agre \\
\hline Weighted Mean & 2.89 & .40 & Agree \\
\hline
\end{tabular}

Legend: Strongly Agree 3.25-4; Agree 2.50-3.24; Disagree 1.75-2.49; Strongly Disagree 1.0-1.74

Most respondents said that delivery is done weekly because the goods have high inventory turnover. However, delivery disruption also happens. As shared among respondents, sometimes their delivery vans were caught in a slow traffic situation, and the delivery truck driver and the laborers resigned in very short notice. The results show a weighted mean of
2.89 or a general response of agreeing to the statements on Delivery Timeliness. This means while there were delays and setbacks, the FMCG Exclusive Distributors find the system generally acceptable. The standard deviation of .40 means the answers of the respondents are homogeneous as it is below 1.0.

\section{Sales Level}

Table 3: Performance of FMCG exclusive distributors on sales level

\begin{tabular}{|c|c|c|c|}
\hline Indicators & Mean & SD & Interpretation \\
\hline $\begin{array}{l}\text { 1. Sales targets are achieved despite the presence of the Chain Grocery } \\
\text { Stores. }\end{array}$ & 3.00 & .77 & Agree \\
\hline $\begin{array}{l}\text { 2. FMCG Exclusive Distributors develop new markets that are not yet } \\
\text { discovered by Chain Grocery Stores. }\end{array}$ & 3.24 & .57 & Agree \\
\hline $\begin{array}{l}\text { 3. An increase in demand or population helps FMCG Exclusive } \\
\text { Distributors achieve sales targets. }\end{array}$ & 3.22 & .52 & Agree \\
\hline $\begin{array}{l}\text { 4. The suppliers (manufacturers and country importers) sell directly to } \\
\text { key Chain Grocery Stores. }\end{array}$ & 2.97 & .89 & Agree \\
\hline $\begin{array}{l}\text { 5. FMCG Exclusive Distributors will survive despite the presence of } \\
\text { the Chain Grocery Stores. }\end{array}$ & 3.42 & .54 & Strongly Agree \\
\hline $\begin{array}{l}\text { 6. The fast growth of Chain Grocery Stores eats up market share from } \\
\text { the distributors. }\end{array}$ & 2.80 & .77 & Agree \\
\hline Weighted Mean & 3.11 & .34 & Agree \\
\hline
\end{tabular}

Legend: Strongly Agree 3.25-4; Agree 2.50-3.24; Disagree 1.75-2.49; Strongly Disagree 1.0-1.74

The respondents strongly agreed that the fast-growing presence of the Chain Grocery exclusive distributors will survive despite the Stores. Two respondents shared that effective 
2020, the major manufacturers have decided to only focus on serving directly the big three chain stores, namely, SM, Puregold, and Robinsons. The smaller Chain Grocery Stores were transferred to the Exclusive Distributors. Further, the Exclusive Distributors aggressively open new accounts - be it a stand-alone grocery store, market stall, or through ex-truck to penetrate side streets to sell directly to the sarisari stores. Moreover, since Chain Grocery Stores usually maintain a modern look (well-lit and air-conditioned), their high operating costs push them to offer higher prices compared with the stand-alone stores. Most FMCG consumers belong to class $\mathrm{D}$ and $\mathrm{E}$ who are price sensitive.
Lastly, according to one respondent the growing population, preference for convenience (near location), and increasing buying power help the exclusive distributors and stand-alone stores.

The results show a weighted mean of 3.11 or a general response of agreeing to the statements on the Sales Level. The standard deviation of .34 means the answers of the respondents are homogeneous as it is below 1.0. This means that despite the fact of not being prioritized compared with the big Chain Grocery Stores, the FMCG Exclusive Distributors' operations are sure to thrive and even grow due to their aggressive marketing strategies, increasing population, and increasing buying power of its target market.

\section{Proliferation of Chain Stores City of Manila}

Table 4: Chain Grocery Stores vs Stand-Alone Grocery Stores with floor area: 300-1,400 sq.m

\begin{tabular}{lcc}
\hline \multicolumn{1}{c}{ Store Category } & \# of Stores & Percentage \\
\hline Chain Stores & 56 & $80 \%$ \\
Stand Alone Grocery Stores & 14 & $20 \%$ \\
\hline Total & 70 & $100 \%$ \\
\hline
\end{tabular}

Based on the data of all registered grocery stores in the City of Manila with a floor area between 300sq.m. and 1,400sq.m., $80 \%$ of the grocery stores are Chain Grocery Stores with a total of 56 , while only $20 \%$ are Stand-Alone Grocery Stores or a total of 14 . This shows that there is an apparent proliferation of Chain Grocery Stores in the City of Manila.

\section{The Population of the City of Manila and the Number of Chain and Stand-Alone Grocery Stores Per Area}

Below is a comparative table of the grocery store concentration in each area in the City of Manila.

Table 5: Grocery Store concentration in the city of Manila per area

\begin{tabular}{lcccccc}
\hline \multicolumn{1}{c}{ Area } & Population & $\begin{array}{c}\text { Population } \\
\text { Percentage }\end{array}$ & $\begin{array}{c}\text { Chain } \\
\text { Stores }\end{array}$ & $\begin{array}{c}\text { Stand Alone } \\
\text { Grocery Stores }\end{array}$ & Total & Percentage \\
\hline Binondo & 12,985 & $0.71 \%$ & 1 & 2 & 3 & $4.29 \%$ \\
Ermita & 10,523 & $0.57 \%$ & 6 & 0 & 6 & $8.57 \%$ \\
Intramuros & 5,935 & $0.32 \%$ & 0 & 0 & 0 & $0.00 \%$ \\
Malate & 78,132 & $4.25 \%$ & 5 & 1 & 6 & $8.57 \%$ \\
Paco & 69,300 & $3.77 \%$ & 3 & 1 & 4 & $5.71 \%$ \\
Pandacan & 76,134 & $4.14 \%$ & 1 & 0 & 1 & $1.43 \%$ \\
Port Area & 66,742 & $3.63 \%$ & 0 & 0 & 0 & $0.00 \%$ \\
Quiapo & 23,138 & $1.26 \%$ & 1 & 0 & 1 & $1.43 \%$ \\
\hline
\end{tabular}




\begin{tabular}{lcccccc}
\hline Sampaloc & 395,111 & $21.50 \%$ & 9 & 1 & 10 & $14.29 \%$ \\
San Miguel & 16,120 & $0.88 \%$ & 0 & 0 & 0 & $0.00 \%$ \\
San Nicolas & 44,241 & $2.41 \%$ & 2 & 0 & 2 & $2.89 \%$ \\
& & & & & & \\
Sta. Ana & 178,769 & $9.73 \%$ & 4 & 1 & 5 & $7.14 \%$ \\
Sta. Cruz & 118,779 & $6.46 \%$ & 10 & 2 & 12 & $17.14 \%$ \\
Sta. Mesa & 110,073 & $5.99 \%$ & 1 & 0 & 1 & $1.43 \%$ \\
Tondo & 631,363 & $34.36 \%$ & 13 & 6 & 19 & $27.14 \%$ \\
\hline Total & $1,837,345$ & $100 \%$ & 56 & 14 & 70 & $100 \%$ \\
\hline
\end{tabular}

Source: Data on the population of the City of Manila is based on the Philippine Statistics Office; while the data on the grocery stores are gathered from the City of Manila-Permits Bureau

The data shows the top 5 most populated areas in the City of Manila, namely: Tondo, Sampaloc, Sta. Ana, Sta.Cruz, then Sta. Mesa. Examining the concentration of grocery stores per area, Tondo has the highest number of grocery stores and consistent with its population size. Other areas with a high presence of grocery stores according to population size are Sta. Cruz, Sampaloc, Ermita, and Malate. This data proves that the grocery stores are concentrated mostly in highly populated residential and university belt areas i.e., Tondo, Sta. Cruz and Sampaloc. Likewise, the grocery stores are present in business districts, namely, Ermita and Malate. Further, results show that there is an opportunity for expansion and market development in some areas in the City of Manila.

\section{Conclusion and Recommendations}

Despite the obvious proliferation of Chain Grocery Stores in the City of Manila, research shows that the FMCG Exclusive Distributors will sustain their operations because of their wide market distribution channel and aggressive marketing strategies as well as increasing consumer spending pattern and population increase, which offset any set back caused by lower fill rates and delays in delivery.

The researchers recommend that the following measures be adopted to ensure a smoother supply chain which is beneficial not only to the FMCG Exclusive Distributors but to manufacturers and country importers as well. The following recommendations are:

\section{Order Fill Rate}

Invest in a modern state-of-art system for order taking that links the grocery stores' purchase order to the FMCG Exclusive Distributors warehouse and purchasing team. This will lessen human errors. Moreover, in seasons when order fill rates are low, FMCG Exclusive Distributors should increase inventory holding. Although the inventory cost will increase, this will offset the opportunity cost for not having stocks on hand. Careful cash management and temporary cash infusion are necessary to tide the distributors over during this period.

\section{Delivery Timeliness}

FMCG Exclusive Distributors should perform time and motion studies with manufacturers and country importers for a realistic delivery schedule. Also, accredit on-call third-party logistics for times when there are truck and manpower shortages to ensure unhampered operations.

\section{Sales Level}

The FMCG Exclusive Distributors have to explore untapped areas. The areas of Paco, Pandacan, Port Area, Sta. Ana, and Sta. Mesa offer opportunities for business expansion for the FMCG Exclusive Distributors.

The three performance indicators, namely: Order Fill Rate, Delivery Timeliness, and Sales Level, presented in-depth information to 
understand the current practices and experiences of the FMCG Exclusive Distributors. The information gathered allowed the researchers to offer specific and realistic courses of action to help the FMCG Exclusive Distributors secure its place in the competitive FMCG Supply Chain and compete with the rapid expansion and proliferation of the big three Chain Grocery Stores.

\section{Acknowledgements}

We would like to thank the following who made significant contributions in making this research paper possible: to our respondents for being cooperative despite the disruption of your work at the height of the Covid -19 pandemic. We laud and thank you for being heroes to help sustain the food supply chain; to the Bureau of Permits staff of the City of Manila LGU for providing us with the data of all registered grocery stores of the City of Manila and to our Graduate School of Business family at the San Beda University, especially our professor, Dr. Divina M. Edralin. Her expertise, patience, and perseverance have widened our perspective and appreciation of the practical application of business research. Our thanks to our statistician, who wish not to be named, for helping us run the validity test of our questionnaire and for performing the statistical computation of our gathered data; to the International Conference on Management in Emerging Markets (ICMEM) organizers and staff who introduced the opportunity to submit our work to the Journal of Business and Social Development (JBSD); to the JBSD secretariat and peer reviewers who patiently reviewed and facilitated the entire journal submission, review, and publication process. We are both humbled and honored. Our appreciation goes to our family and friends who cheered us on throughout this journey. Last but not the least, to God Almighty for the endless mercies and graces. May You be glorified for your wondrous deed.

\section{References}

Andrada, M. F., Prudenciano, H. L., \& Reyes, J. B. (2020). Layout Design Model for Independent Grocery Stores in the Philippines. Proceedings of the International Conference on Industrial Engineering and Operations Management, 1719-1731.

Chung, C., Chatterjee, S., \& Sengupta, S. (2012). Manufacturers' reliance on channel intermediaries: Value drivers in the presence of a direct web channel. Industrial Marketing Management, ISSN: 0019-8501, 41(1), 40-53. DOI:10.1016/j. indmarman.2011.11.010

Digal, L. (2015). Modern Retail Food Sector in the Philippines: Dominance of large domestic retailers and their effects on the supply chain. The International Review of Retail, Distribution and Consumer Research, 25(4). DOI:10.1080/09593969.2 015.1023214

Johnson, A., \& Nagarur, N. (2012). A discussion on supply chain robustness and resiliency. 62nd IIE Annual Conference and Expo 2012, 3414-3423.

Mandal, K., Bandyopadhyay, G., \& Roy, K. (2011). Quest for different strategic dimensions of channel management: An empirical study. Journal of Business Studies Quarterly 2011, 3(2), 25-44. DOI:10.1.1.651.7521

Nyaga, J. (2014). Factors affecting distribution of fast moving consumer goods in Kenya: A case of Eveready East Africa. International Journal of Social Sciences and Entrepreneurship, 1(12). Retrieved from http://ijsse.org/articles/ijsse_v1_ i12_290_302.pdf

Patra, G. (2016). Distribution and promotion effectiveness on sales - A study of retailer perception. Splint International Journal of Professionals: A Quarterly Peer Reviewed Multi-disciplinary International Journal; Bhubaneswar, 3(9), 74-83. 
Rangel, D., de Olivera, T., \& Leite, M. (2014). Supply chain risk classification: Discussion and proposal. International Journal of Production Research, 53(2015), 68686887. DOI:10.1080/00207543.2014.91062 0

Rubio, J. (2019). Food Retail Sectoral Report. Manila: FAS Manila.

Sarkar, D. (2013). Rural delivery mechanisms from rural FMCG distributors to rural retailers: A framework to maximize retailer satisfaction. JIM QUEST, 9(1), 28-41.

Sayed,H.(2013). Supply Chain Key Performance Indicators Analysis. International Journal of Application or Innovation in Engineering \& Management, 2(1). Retrieved from https://www.ijaiem.org/volume2Issue1/ IJAIEM-2013-01-28-059.pdf
Sheth, P. (2019). FMCG Distributors cry fowl over deep discounts, higher margins for modern trade. Mumbai: CNBC-TV18 Digital.

Tetteh, A., \& Xu, Q. (2014). Supply chain distribution networks: Single-, dual- and Omni-channel. Interdisciplinary Journal of Research in Business, 3(09), 63-73.

Trihatmoko, R., \& Mulyani, R. (2018). Distribution strategy for new product marketing success: Fast Moving Consumer Goods (FMCG) business. Management and Human Resource Research Journal, 7(12), 19-32.

Trihatmoko, R., Mulyani, R., \& Lukviarman, N. (2018). Product placement strategy in the business market competition: Studies of fast moving consumer goods. Business and Management Horizons, 2018, 6, 150-161. DOI:105296/bmh. v6i1.13239 
